\title{
Interpreting the Past Through Miniature Objects
}

Von: Ryan Nutting

"Don't put it in your pocket. It's your lucky quarter... it'll get mixed in with the others and become just a coin. Which it is." - Anton Chigurh, No Country for Old Men

Near the conclusion of the scene inside the gas station in the film No Country for Old Men, the antagonist Anton Chigurh assigns a new meaning to an everyday object - a quarter of a dollar. While affirming that is just a coin he also states that it is now the proprietor's lucky coin as he just won a coin flip with it (and likely saved his own life by correctly guessing the result). Through this statement Chigurh adds new information to this object and changes its interpretation, adding to the biography of this coin.

Much of my previous research has focused on the construction and conveyance of knowledge through material culture including the changing meaning of objects and how objects acquire new meanings. I believe tracking the changing meanings of objects gets at the heart of how museums construct and present information on the world. During my PhD research I examined how the interpretation of miniature objects purchased by tea merchant, museum founder, and Member of Parliament Frederick Horniman (1835-1906) changed between 1894 and 1898 as interpreted by Horniman himself, the Horniman Free Museum, and a museum visitor.

This methodology, known as biography of objects, argues that the meaning of objects can vary depending upon when and by whom objects are interpreted. This approach does not focus on one instance in the life of an object. Instead, similar to constructing the biography of a person, an object's biography seeks to understand how the meaning of an object changes and the multiple contexts in which people used or viewed it. There is not one way to create an object's biography. Construing objects in this way can, for example, include information about the object's creation, materials, or interpretation from multiple perspectives.

While at the KWI I have been examining the biography of a group of Japanese netsuke held by the Museum Folkwang and the museum's changing interpretation of these objects since 2010. A netsuke is a small sculpture, depicting a wide variety of real or imaginary animals, places, people, or events, often carved from wood, horn or ivory. They were worn above the belt and connected via a cord for use as a counterbalance to an inro (small case), or other types of sagemono (suspended objects) as part of Japanese men's clothing that did not contain pockets. Likely originating during the Edo period (1603-1868) these objects stopped being used as functional objects during the late nineteenth and early twentieth centuries with the introduction of Western fashions with pockets. During 
the nineteenth and twentieth centuries these objects also became collector's items primarily in the USA and Europe. Netsuke usually measured between two to six centimeters in height and often featured two holes, usually camouflaged in their design, for the cord. They often served as symbols of social status and could be as simple as a small stick with two holes or intricately carved designs and have been featured in works such as The Hare with Amber Eyes by Edmund de Waal.

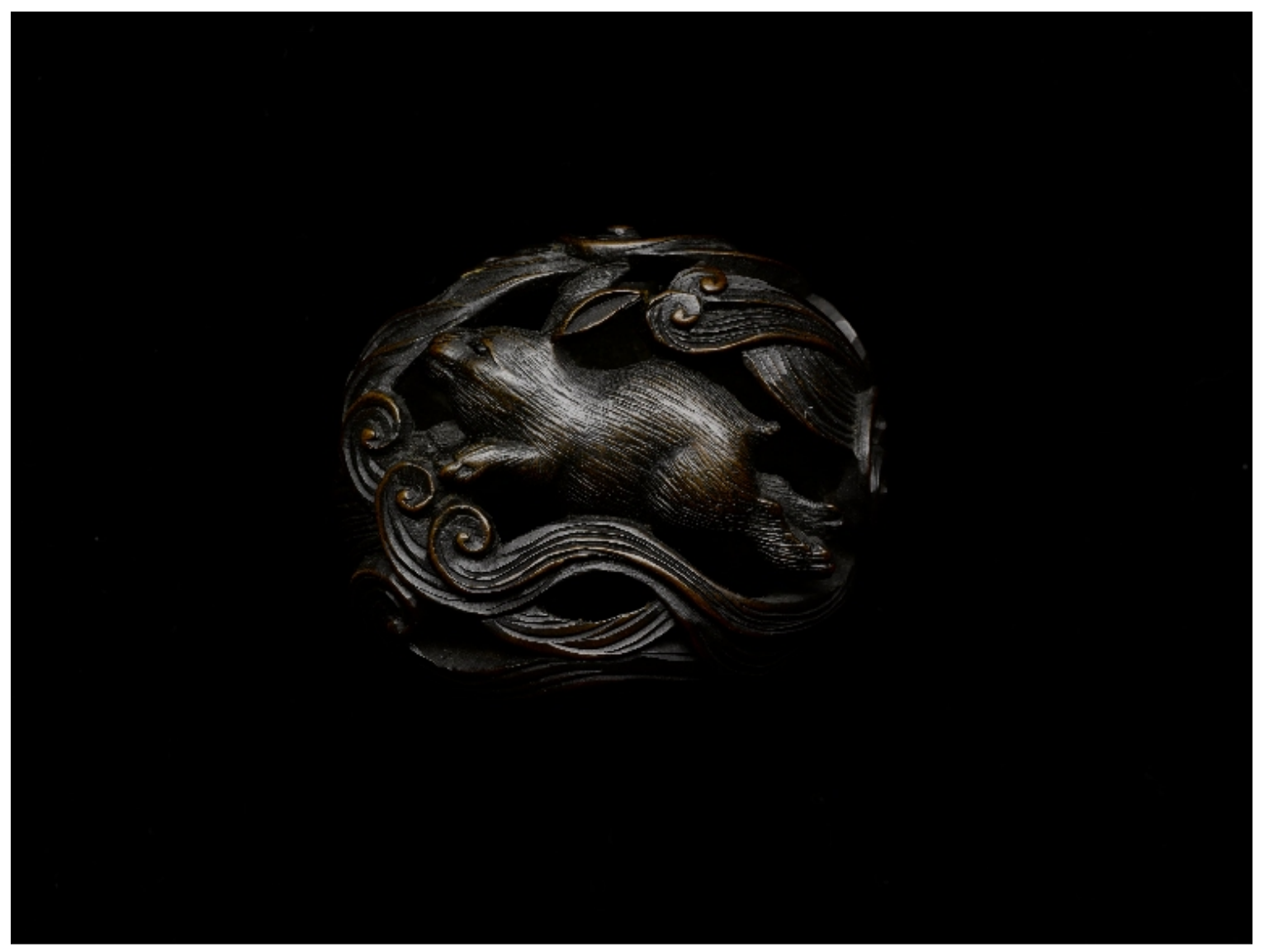

Figure 1: Museum Folkwang object KPL 92 (Photo: Museum Folkwang Essen)

Figure 1 shows a netsuke in the shape of a hare in a wave pattern (KPL 92 in the collection of the Folkwang Museum), which exemplifies these characteristics of a netsuke. First, it is small as it measures $3.27 \times 3.8 \times 2.1 \mathrm{~cm}$ and is constructed of boxwood with inlays of horn and ivory. It also represents an animal - in this case a hare which could symbolize well known Asian hares or rabbits such as an animal in the Chinese zodiac, the rabbit who lives on the moon in Asian folklore, or the Japanese story of the hare of Inaba. The holes in this object constructed for a cord are obscured within the wave pattern surrounding the hare. Although the museum does not provide an approximate date for the creation of this object, museum records indicate this object entered the collection of the museum when it opened in 1902, thereby dating its construction prior to 1902.

The museum added to the biography of the object by including it in two recent exhibitions: "'Das Schönste Museum der Welt'. Museum Folkwang bis 1933" ('The Most Beautiful Museum in the World'. Folkwang Museum until 1933) which ran from 20 March 2010 to 
25 July 252010 and "Monet, Gaugin, van Gogh... Inspiration Japan" which ran from 27 September 2014 to 18 January 2015 to reflect the interest in collecting Japanese materials in the late nineteenth and early twentieth century known as Japonism.

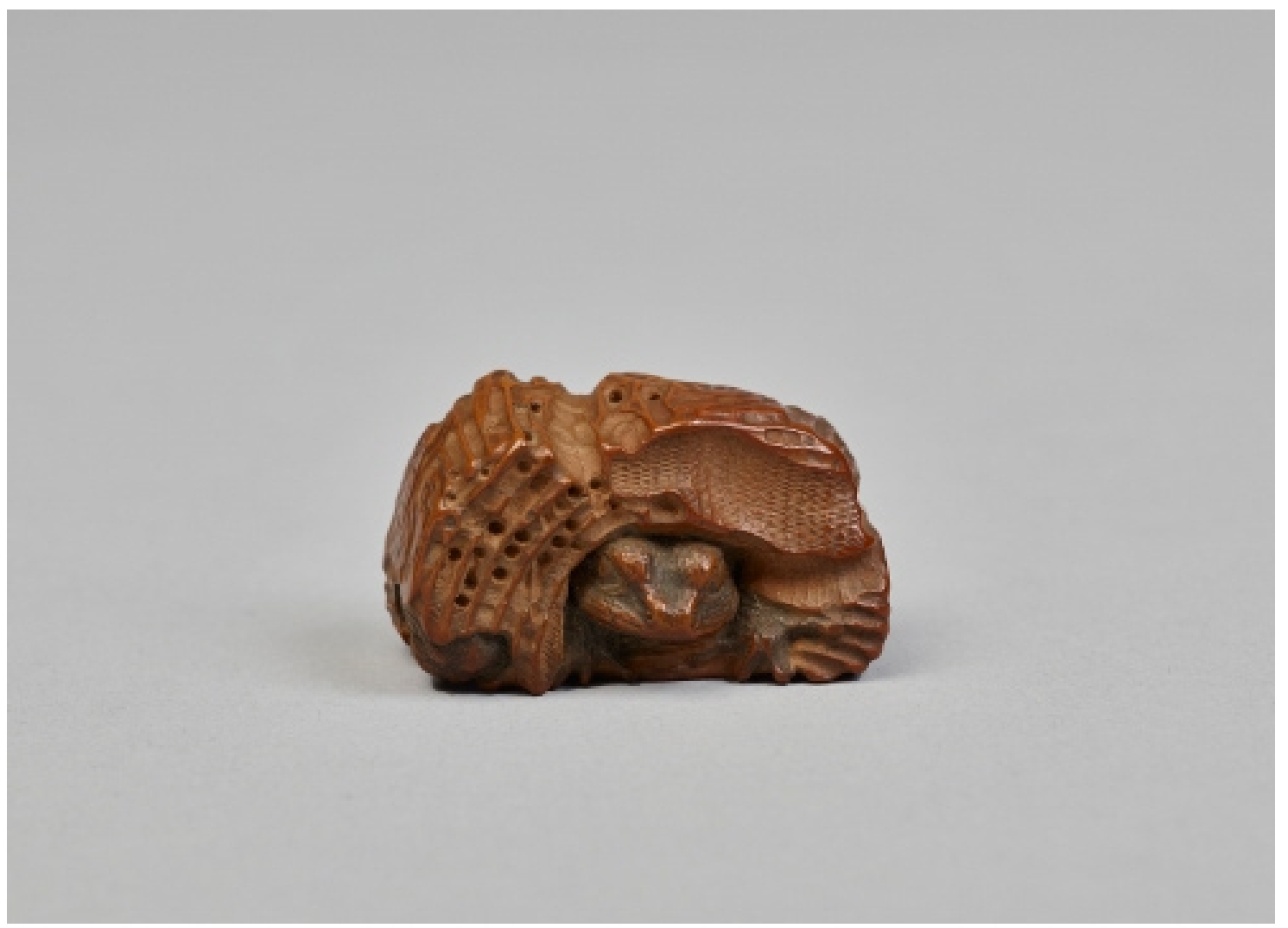

Figure 2: Museum Folkwang object KPL 98 (Photo: Museum Folkwang Essen)

As part of my project at the KWI I am examining Museum Folkwang number KPL 98 - a netsuke depicting a toad peering out of a hole in a log (Figure 2). It measures $2.6 \times 4.4 \mathrm{x}$ $2.6 \mathrm{~cm}$ and is approximately dated to the eighteenth century. Museum records show this object was acquired in 1901, and, like the hare netsuke, entered the museum's collections in 1902, possibly also reflecting Japonism. This netsuke is constructed of light boxwood (possibly fruitwood) and features a toad sitting in a hollowed-out piece of wood peering straight forward. The two front feet of the toad are visible along the base of the object grasping the wood. The right side and back of the trunk are cut away to reveal more of the toad. The object features several small holes along the front, top, and right side of the object and two larger holes on the bottom. This item bears a maker's mark in slightly elevated characters on the bottom of the object. The museum has identified this mark as referring to the Mitani Goho School in Iwami, which specialized in wooden carvings.

Like the rabbit netsuke, this object has been included in recent exhibitions at the Museum Folkwang including the two exhibitions mentioned above as well as the current exhibition "Der Fisch im Schafspelz" (The Fish in Sheep's Clothing) as part of the New Worlds exhibition. The museum's different interpretation of this one object across these three exhibitions contributes to this object's biography. 
The first of these exhibitions ('Das Schönste Museum der Welt' Museum Folkwang bis 1933") focused on recreating the original collection of the Museum Folkwang. To this end, the museum included objects in its collection when the museum opened as well as borrowed objects from collectors and other museums in order to detail the vision of the museum's founder Karl Osthaus. Following this idea, the museum placed this netsuke toad, along with other netsuke in Room 12 of the exhibition. This room focused on Asian ceramics and lacquerware dating from the second century $B C$ to the nineteenth century $A D$ collected by Osthaus and the early museum. Consequently, the museum highlighted the Asian origin of the object and its materiality as well as the fact that the museum originally collected this object in the early twentieth century.

Although the exhibition "Monet, Gaugin, van Gogh... Inspiration Japan" also emphasized the Japanese origins of this netsuke toad and included it with a group of other netsuke, the interpretation of the object greatly differed. With this exhibition, the museum sought to show the Japanese influences on Western art including Japanese art and everyday objects. A label produced by the museum placed emphasis on this object as a part of Japanese clothing. This label encouraged visitors to think about the symbolic meaning of animals, touch materials similar to this object and discuss their experiences, and think about what form their own netsuke may take. In this way, the museum shifted the interpretation of this object to a teaching tool to engage visitors into thinking about the use, materials, and representational nature of these objects.

The museum also includes this object in its current exhibition "Der Fisch im Schafspelz". Differing from the two exhibitions discussed above, this exhibition does not present information on the origin of this object, but instead focuses on the role and motifs of animals in our lives. The museum placed the toad netsuke on a shelf with an incense burner in the shape of a frog (See Figure 3- Museum Folkwang object K 276) and a netsuke depicting an octopus in a jar (See Figure 4- Museum Folkwang object KPL 91) Through this placement, the museum encourages visitors to closely examine objects and compare objects depicting similar themes. 


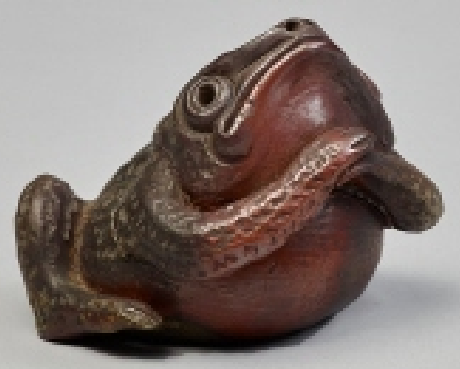

Figure 3: Museum Folkwang object K 276 (Photo: Museum Folkwang Essen) 


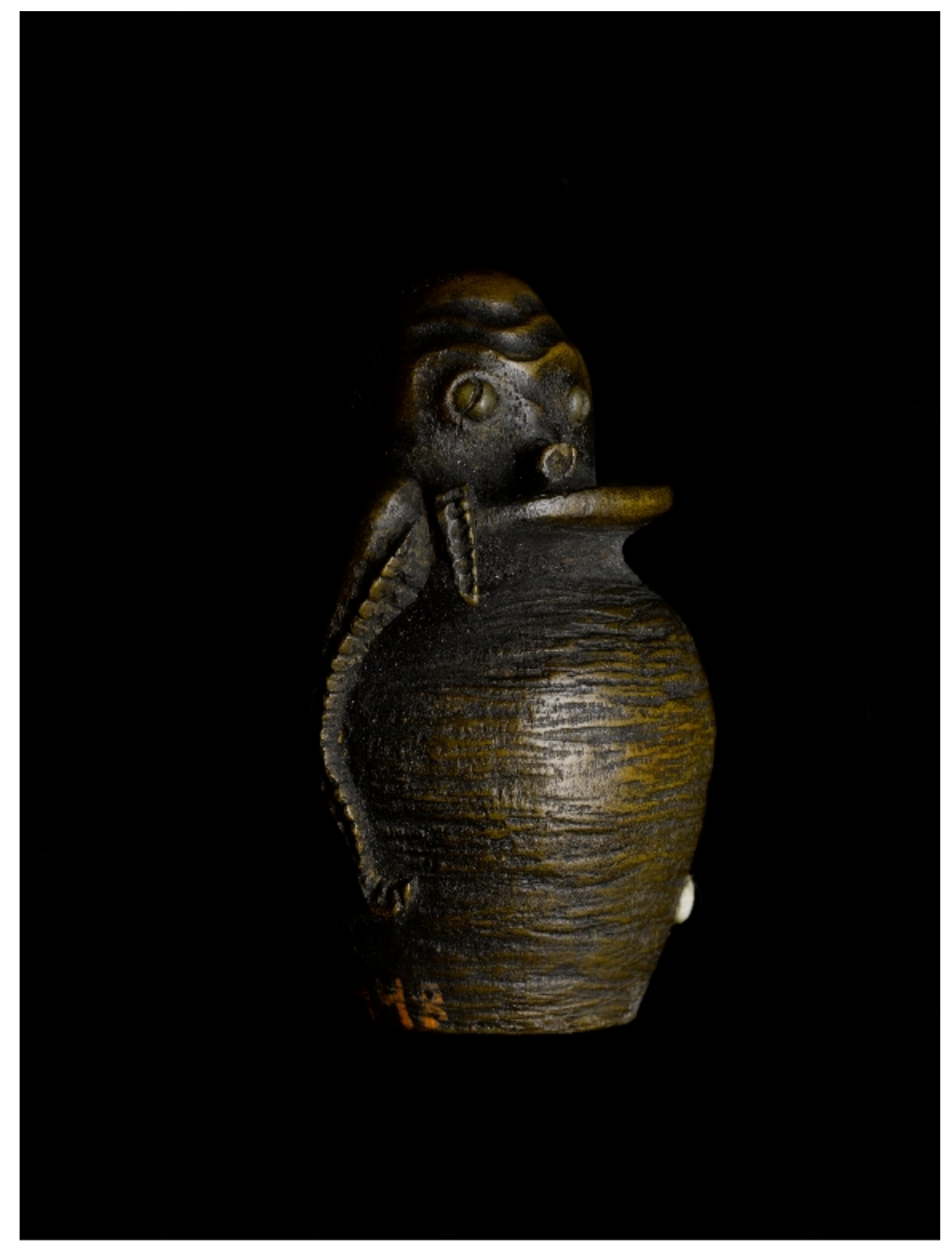

Figure 4: Museum Folkwang object KPL 91 (Photo: Museum Folkwang Essen)

This interpretation is confirmed by a video the museum created with Curator Dr Nadine Engel where she contrasts three objects depicting snakes in the exhibition, and encourages closer inspection of the objects on display using the $\mathrm{HORCH}$ Animal created by Rudolf Belling as an example.

When I first entered the Helmet in the New Worlds exhibition at the Folkwang Museum I immediately began searching for the toad netsuke in the museum. I worried that this small object would be overwhelmed in this 4.5-meter sculpture that is also intended to display small objects. However, both when in the helmet, and walking around the helmet I 
also found this exhibition allowed for and encouraged a closer viewing experience and closer inspection of the objects. This exhibition can be toured virtually in both German and English.

Click here for the German tours:

- Neue Welten

- Der Fisch im Schafspelz

and here for the English tours:

- New Worlds

- The Fish in Sheep's Clothing

Based on this example of a netsuke toad you can see how the interpretation of this object has changed dramatically since 2010 . Although it was originally purchased and collected to be a part of the Folkwang Museum at the turn of the twentieth century the museum has exhibited it to represent examples of Japanese art and Japonism, a teaching tool for understanding the forms and materials of netsuke, and to think about representations of animals. Also, like the coin mentioned at the top of this piece, it acquired news meanings based on its interpretation.

Do you have or collect objects with which you associate more than one meaning over time such as a lucky coin, hat, or another type of object with which you have associated additional or new meanings?

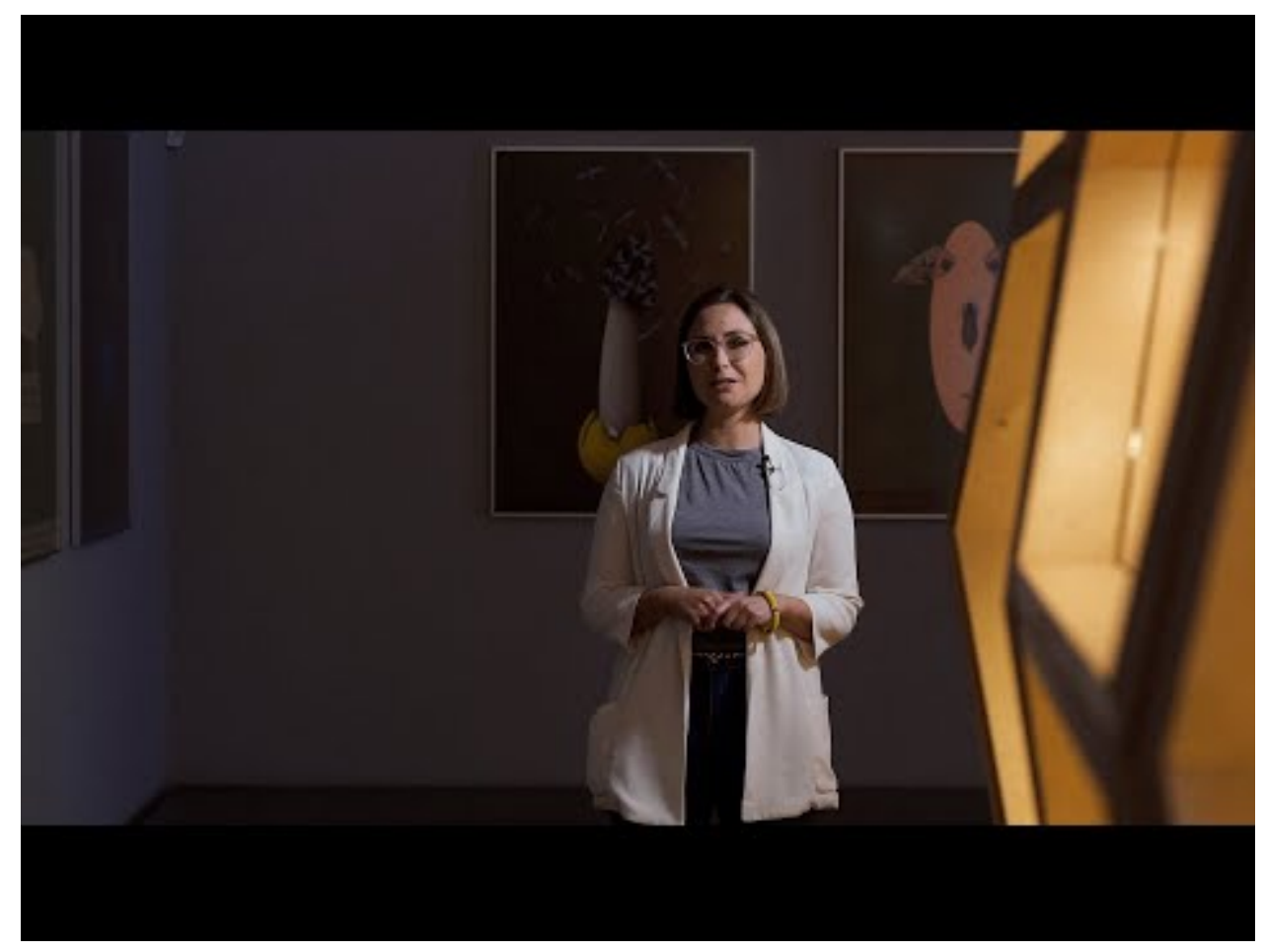

SUGGESTED CITATION: Nutting, Ryan: Interpreting the Past Through Miniature Objects, in: KWI-BLOG, [https://blog.kulturwissenschaften.de/interpreting-throughminiature-objects/], 15.03.2021 


\section{Ryan Nutting}

Historian with a PhD in Museum Studies, joined the KWI as an International Fellow in October 2020. Research focuses: history of museums and museum collections including the collecting, interpreting, and changes in the interpretation of material culture, specifically miniature models. While at the KWI Ryan has been researching the changes in the interpretation of collections of miniature models at the Museum Folkwang.

\section{$\underline{\text { Vita }}$}

"Don't put it in your pocket. It's your lucky quarter... it'll get mixed in with the others and become just a coin. Which it is." - Anton Chigurh, No Country for Old Men

Near the conclusion of the scene inside the gas station in the film No Country for Old Men, the antagonist Anton Chigurh assigns a new meaning to an everyday object - a quarter of a dollar. While affirming that is just a coin he also states that it is now the proprietor's lucky coin as he just won a coin flip with it (and likely saved his own life by correctly guessing the result). Through this statement Chigurh adds new information to this object and changes its interpretation, adding to the biography of this coin.

Much of my previous research has focused on the construction and conveyance of knowledge through material culture including the changing meaning of objects and how objects acquire new meanings. I believe tracking the changing meanings of objects gets at the heart of how museums construct and present information on the world. During my PhD research I examined how the interpretation of miniature objects purchased by tea merchant, museum founder, and Member of Parliament Frederick Horniman (1835-1906) changed between 1894 and 1898 as interpreted by Horniman himself, the Horniman Free Museum, and a museum visitor.

This methodology, known as biography of objects, argues that the meaning of objects can vary depending upon when and by whom objects are interpreted. This approach does not focus on one instance in the life of an object. Instead, similar to constructing the biography of a person, an object's biography seeks to understand how the meaning of an object changes and the multiple contexts in which people used or viewed it. There is not one way to create an object's biography. Construing objects in this way can, for example, include information about the object's creation, materials, or interpretation from multiple perspectives.

While at the $\mathrm{KWI}$ I have been examining the biography of a group of Japanese netsuke held by the Museum Folkwang and the museum's changing interpretation of these objects since 2010. A netsuke is a small sculpture, depicting a wide variety of real or imaginary animals, places, people, or events, often carved from wood, horn or ivory. They were 
worn above the belt and connected via a cord for use as a counterbalance to an inro (small case), or other types of sagemono (suspended objects) as part of Japanese men's clothing that did not contain pockets. Likely originating during the Edo period (1603-1868) these objects stopped being used as functional objects during the late nineteenth and early twentieth centuries with the introduction of Western fashions with pockets. During the nineteenth and twentieth centuries these objects also became collector's items primarily in the USA and Europe. Netsuke usually measured between two to six centimeters in height and often featured two holes, usually camouflaged in their design, for the cord. They often served as symbols of social status and could be as simple as a small stick with two holes or intricately carved designs and have been featured in works such as The Hare with Amber Eyes by Edmund de Waal.

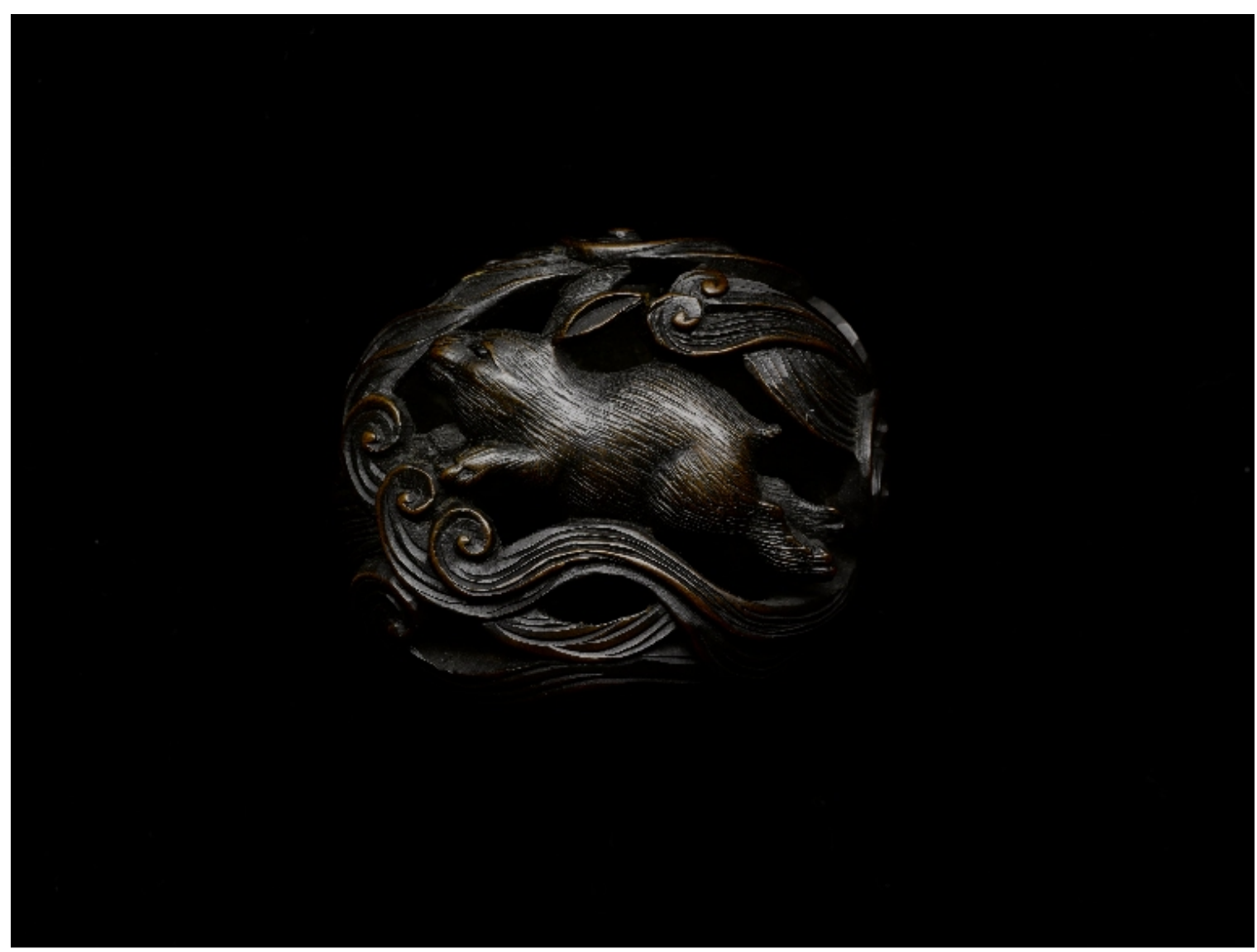

Figure 1: Museum Folkwang object KPL 92 (Photo: Museum Folkwang Essen)

Figure 1 shows a netsuke in the shape of a hare in a wave pattern (KPL 92 in the collection of the Folkwang Museum), which exemplifies these characteristics of a netsuke. First, it is small as it measures $3.27 \times 3.8 \times 2.1 \mathrm{~cm}$ and is constructed of boxwood with inlays of horn and ivory. It also represents an animal - in this case a hare which could symbolize well known Asian hares or rabbits such as an animal in the Chinese zodiac, the rabbit who lives on the moon in Asian folklore, or the Japanese story of the hare of Inaba. The holes in this object constructed for a cord are obscured within the wave pattern surrounding the hare. Although the museum does not provide an approximate date for the creation of this object, museum records indicate this object entered the collection of the museum when it opened in 1902, thereby dating its construction prior to 1902. 
The museum added to the biography of the object by including it in two recent exhibitions: "'Das Schönste Museum der Welt'. Museum Folkwang bis 1933" ('The Most Beautiful Museum in the World'. Folkwang Museum until 1933) which ran from 20 March 2010 to 25 July 252010 and "Monet, Gaugin, van Gogh... Inspiration Japan" which ran from 27 September 2014 to 18 January 2015 to reflect the interest in collecting Japanese materials in the late nineteenth and early twentieth century known as Japonism.

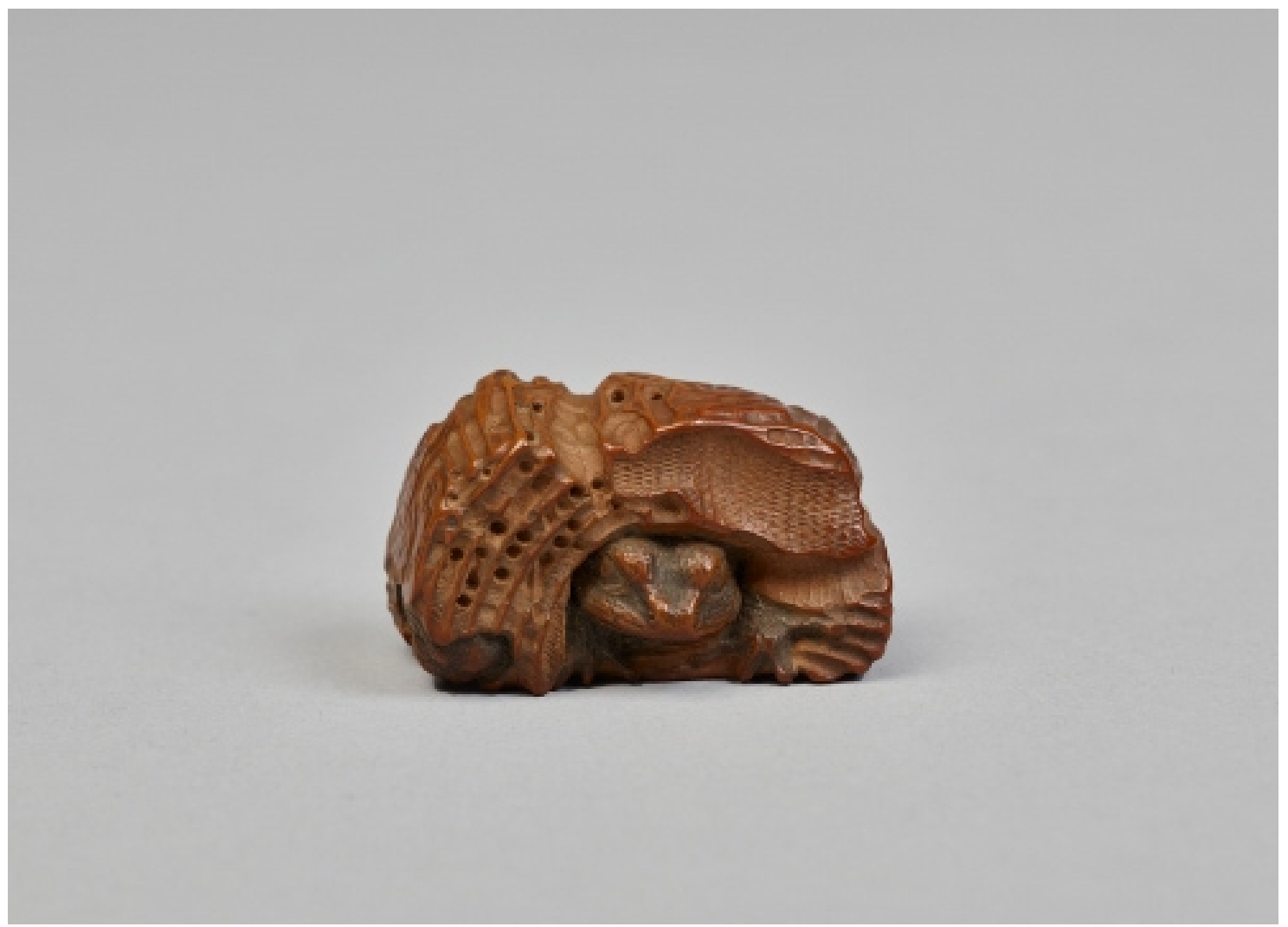

Figure 2: Museum Folkwang object KPL 98 (Photo: Museum Folkwang Essen)

As part of my project at the KWI I am examining Museum Folkwang number KPL 98 -a netsuke depicting a toad peering out of a hole in a log (Figure 2). It measures $2.6 \times 4.4 \mathrm{x}$ $2.6 \mathrm{~cm}$ and is approximately dated to the eighteenth century. Museum records show this object was acquired in 1901, and, like the hare netsuke, entered the museum's collections in 1902, possibly also reflecting Japonism. This netsuke is constructed of light boxwood (possibly fruitwood) and features a toad sitting in a hollowed-out piece of wood peering straight forward. The two front feet of the toad are visible along the base of the object grasping the wood. The right side and back of the trunk are cut away to reveal more of the toad. The object features several small holes along the front, top, and right side of the object and two larger holes on the bottom. This item bears a maker's mark in slightly elevated characters on the bottom of the object. The museum has identified this mark as referring to the Mitani Goho School in Iwami, which specialized in wooden carvings.

Like the rabbit netsuke, this object has been included in recent exhibitions at the Museum Folkwang including the two exhibitions mentioned above as well as the current exhibition "Der Fisch im Schafspelz" (The Fish in Sheep's Clothing) as part of the New Worlds 
exhibition. The museum's different interpretation of this one object across these three exhibitions contributes to this object's biography.

The first of these exhibitions ("'Das Schönste Museum der Welt' Museum Folkwang bis 1933") focused on recreating the original collection of the Museum Folkwang. To this end, the museum included objects in its collection when the museum opened as well as borrowed objects from collectors and other museums in order to detail the vision of the museum's founder Karl Osthaus. Following this idea, the museum placed this netsuke toad, along with other netsuke in Room 12 of the exhibition. This room focused on Asian ceramics and lacquerware dating from the second century BC to the nineteenth century $A D$ collected by Osthaus and the early museum. Consequently, the museum highlighted the Asian origin of the object and its materiality as well as the fact that the museum originally collected this object in the early twentieth century.

Although the exhibition "Monet, Gaugin, van Gogh... Inspiration Japan" also emphasized the Japanese origins of this netsuke toad and included it with a group of other netsuke, the interpretation of the object greatly differed. With this exhibition, the museum sought to show the Japanese influences on Western art including Japanese art and everyday objects. A label produced by the museum placed emphasis on this object as a part of Japanese clothing. This label encouraged visitors to think about the symbolic meaning of animals, touch materials similar to this object and discuss their experiences, and think about what form their own netsuke may take. In this way, the museum shifted the interpretation of this object to a teaching tool to engage visitors into thinking about the use, materials, and representational nature of these objects.

The museum also includes this object in its current exhibition "Der Fisch im Schafspelz". Differing from the two exhibitions discussed above, this exhibition does not present information on the origin of this object, but instead focuses on the role and motifs of animals in our lives. The museum placed the toad netsuke on a shelf with an incense burner in the shape of a frog (See Figure 3- Museum Folkwang object K 276) and a netsuke depicting an octopus in a jar (See Figure 4- Museum Folkwang object KPL 91) Through this placement, the museum encourages visitors to closely examine objects and compare objects depicting similar themes. 


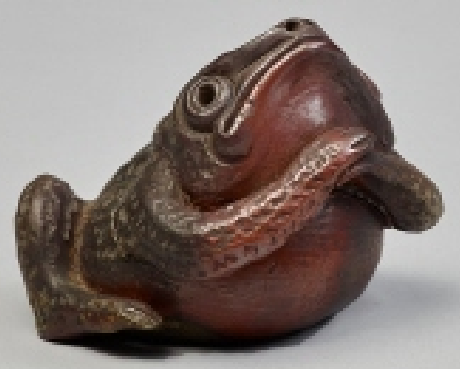

Figure 3: Museum Folkwang object K 276 (Photo: Museum Folkwang Essen) 


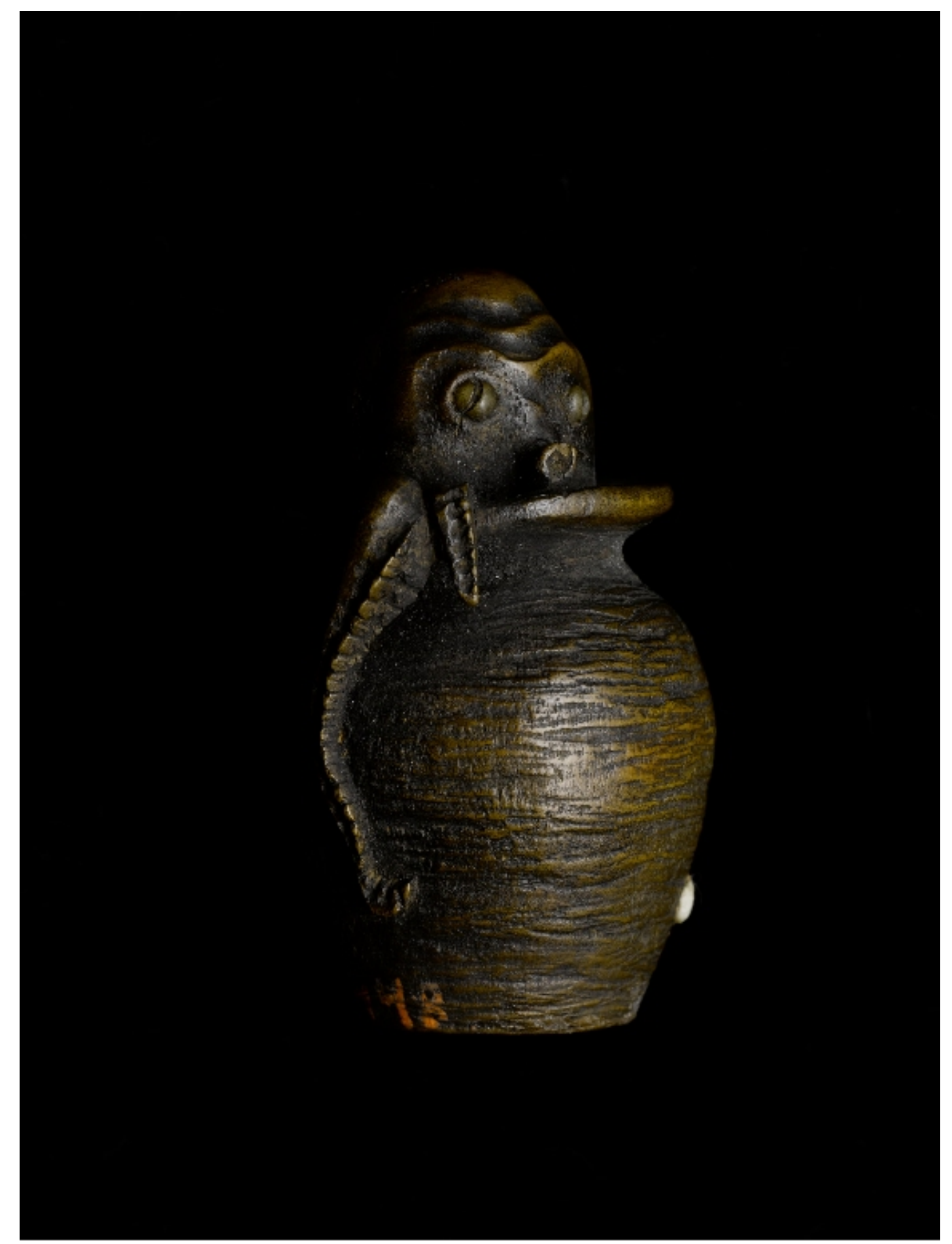

Figure 4: Museum Folkwang object KPL 91 (Photo: Museum Folkwang Essen)

This interpretation is confirmed by a video the museum created with Curator Dr Nadine Engel where she contrasts three objects depicting snakes in the exhibition, and encourages closer inspection of the objects on display using the $\mathrm{HORCH}$ Animal created by Rudolf Belling as an example.

When I first entered the Helmet in the New Worlds exhibition at the Folkwang Museum I immediately began searching for the toad netsuke in the museum. I worried that this small object would be overwhelmed in this 4.5-meter sculpture that is also intended to display small objects. However, both when in the helmet, and walking around the helmet I 
also found this exhibition allowed for and encouraged a closer viewing experience and closer inspection of the objects. This exhibition can be toured virtually in both German and English.

Click here for the German tours:

- Neue Welten

- Der Fisch im Schafspelz

and here for the English tours:

- New Worlds

- The Fish in Sheep's Clothing

Based on this example of a netsuke toad you can see how the interpretation of this object has changed dramatically since 2010 . Although it was originally purchased and collected to be a part of the Folkwang Museum at the turn of the twentieth century the museum has exhibited it to represent examples of Japanese art and Japonism, a teaching tool for understanding the forms and materials of netsuke, and to think about representations of animals. Also, like the coin mentioned at the top of this piece, it acquired news meanings based on its interpretation.

Do you have or collect objects with which you associate more than one meaning over time such as a lucky coin, hat, or another type of object with which you have associated additional or new meanings?

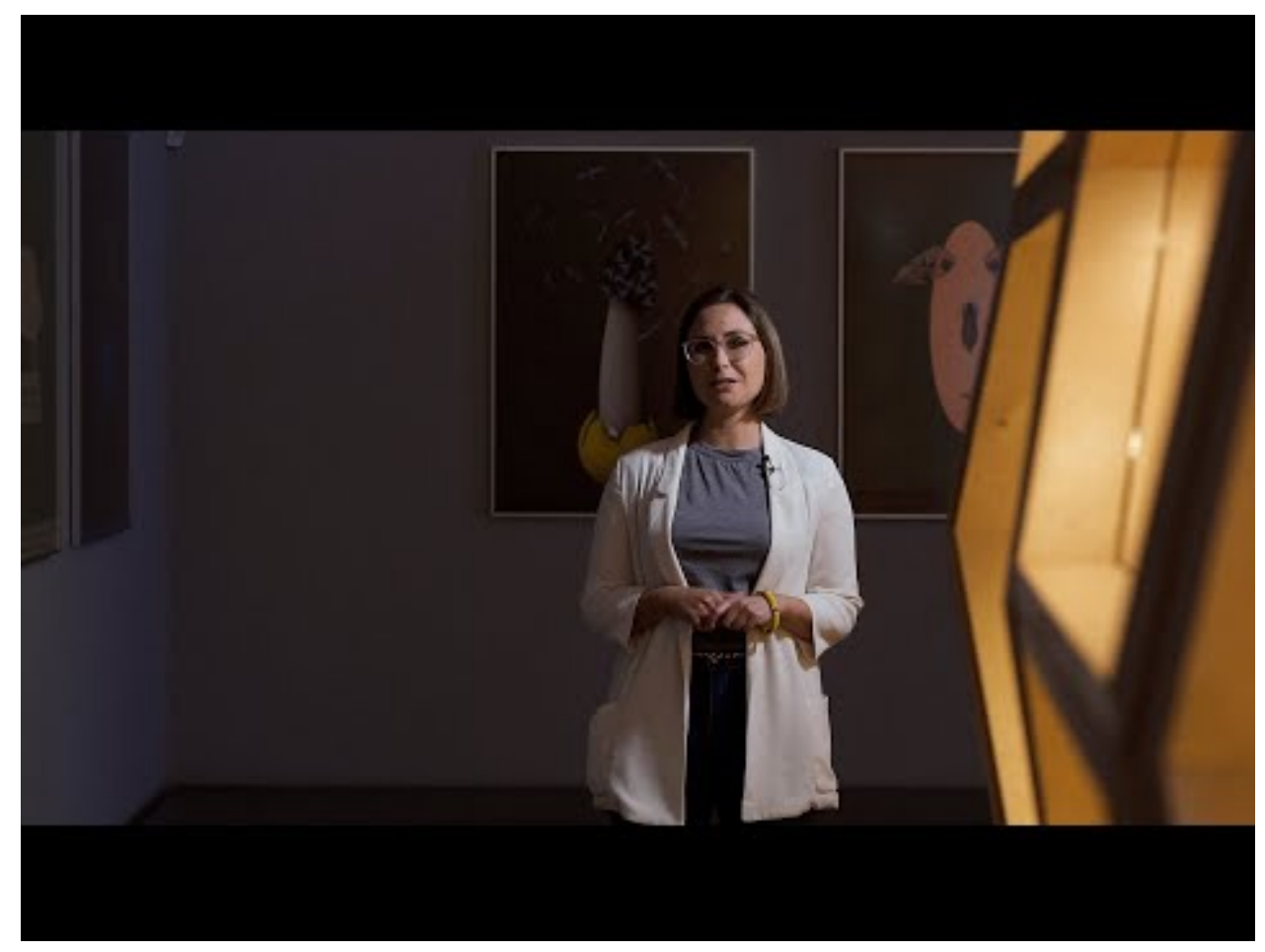

Unser Institut besteht nicht nur aus den fachlichen Publikationen und Auftritten von Einzelnen und Gruppen in ihren jeweiligen fachlichen Feldern und Formaten. Das KWI wird auch als forschende, argumentierende und reflektierende Institution wahrgenommen; als Adresse, die für bestimmte Fragestellungen und Anregungen, und 
vielleicht sogar für einen intellektuellen Stil steht. Dies nicht im Sinne eines personalisierbaren Auftritts, sondern als Denkbewegung einer Gruppe und ihrer Gäste und Partner*innen.

Der Blog soll uns als Forschungsort noch erkennbarer machen und unsere Arbeit zur Diskussion stellen: Forschungsergebnisse und Thesen, Interventionen und Kritik, epistemische und formale Experimente, Lagebeschreibungen und Szenen aus dem Wissenschaftsalltag. Diese können von einzelnen oder mehreren vorgetragen werden, auch in vielstimmiger Weise, als Dialoge, Streitgespräche oder Interviews.

Gast-Beiträge sind nach Rücksprache erwünscht, ebenso Vielfalt - aber mit erkennbarem Bezug zu unserer wissenschaftlichen Arbeit und ihren politischen Implikationen. Wir wünschen uns und Ihnen gut lesbare Texte, die sich an wissenschaftlich tätige und an wissenschaftlich interessierte Leserinnen und Leser richten.

Essen, im März 2020

Julika Griem

Folgende Blogs möchten wir gerne empfehlen:

Alltag in der Krise

AufRuhr

Avenue

54 Books

Conscientious

Geschichte der Gegenwart

Hypotheses

Ideenfreiheit

In the Moment

L.I.S.A.

Literaturwissenschaft in Berlin

Marta Blog

Merkur-Blog

NOMOI - Manifestation and Iconology of Law

NoVaMigra.Blog

Sozblog

Soziopolis

Städel Blog

Still Searching...

Theorieblog.de

Essen, September 2020 
This text is made available via DuEPublico, the institutional repository of the University of Duisburg-Essen. This version may eventually differ from another version distributed by a commercial publisher.

DOI: $\quad 10.37189 / \mathrm{kwi}-\mathrm{blog} / 20210315-0830$

URN: urn:nbn:de:hbz:464-20210315-103202-7 